Гомон И.В., Макарова А.

\title{
Оценка таможенного контроля ФТС России по обеспечению уплаты таможенных платежей
}

Калужский Государственный Университет имени К. Э. Циолковского

(Россия, Калуга)

doi: $10.18411 / \mathrm{j}-06-2021-115$

Научный руководитель

Гомон И.В.

\section{Аннотация}

В статье дается оценка таможенного контроля ФТС России по обеспечению уплаты таможенных платежей. Произведен анализ таможенных платежей за последние три года.

Ключевые слова: таможенные платежи, таможенные органы, единый лицевой счет, ВЭД, таможенные пошлины, электронный документ, налоги.

\section{Abstract}

The article gives an assessment of the customs control of the Federal Customs Service of Russia to ensure the payment of customs duties. The analysis of customs payments for the last three years is made.

Keywords: customs payments, customs authorities, single personal account, foreign trade, customs duties, electronic document, taxes.

В 2020 году ФТС России реализовала комплекс мер, направленных на упрощение условий ведения бизнеса и улучшение бизнес-климата в Российской Федерации.

Все таможенные органы использовали технологию централизованного учета таможенных и иных платежей, уплачиваемых участниками внешнеэкономической деятельности с использованием единого ресурса лицевых счетов плательщиков таможенных пошлин, налогов (далее - ЕЛС), открытых на уровне Федеральной таможенной службы России.

С декабря 2020 года возможность использования преимуществ ЕЛС открыта для всех плательщиков таможенных и иных платежей, сбор которых возложен на таможенные органы, в том числе на иностранных лиц, не состоящих на учете в налоговых органах Российской Федерации. Для таких лиц при предоставлении таможенному органу идентифицирующих их сведений процесс учета таможенных платежей максимально автоматизирован.

По состоянию на 31 декабря 2020 года в ресурсе ЕЛС открыт 881631 (в 2018 году 77 278, а в 2019 - 396 454) лицевой счет плательщиков таможенных пошлин, налогов, в том числе [1]:

— 180920 единых лицевых счетов юридических лиц России;

- 692 единых лицевых счета иностранных юридических лиц, зарегистрированных в налоговых органах Российской Федерации;

- 483 единых лицевых счета иностранных юридических лиц, не зарегистрированных в налоговых органах Российской Федерации;

- 697080 единых лицевых счетов физических лиц и индивидуальных предпринимателей, зарегистрированных в налоговых органах Российской Федерации;

- 3086 единых лицевых счетов иностранных физических лиц, не зарегистрированных в налоговых органах Российской Федерации. 
Продолжена работа по совершенствованию информационного сервиса «Личный кабинет» Личного кабинета участника ВЭД (далее - Личный кабинет): реализована функция, позволяющая плательщикам самостоятельно уточнять ошибочно указанную информацию в расчетных (платежных) документах при заполнении реквизитов кода бюджетной классификации, ИНН и КПП получателя (ФТС России); с ноября 2020 года в режиме апробации участникам ВЭД предоставлена возможность подавать заявки на возврат авансовых платежей в электронном виде.

На 2020 год таможенными органами принято обеспечение исполнения обязанности по уплате таможенных пошлин, налогов на общую сумму более 762,8 млрд рублей, что на 15\% выше значения аналогичного показателя 2019 года. В 2019 году таможенные органы собрали таможенных платежей и пеней в размере 22,2 млрд рублей, в том числе таможенных платежей - 20,7 млрд рублей, штрафов - 1,5 млрд рублей. По сравнению с 2018 годом сумма взыскания задолженности по уплате таможенных пошлин и пеней увеличилась на 9,7 млрд рублей или в 1,8 раза [1].

Основная часть этой суммы $(75,8 \%)$ - это поручительство, принятое таможенными органами, при этом основная часть поручительства была предоставлена при транзите товаров (99,9\% от общей суммы принятого поручительства).

В 2020 году таможенные органы приняли 19,9 тыс. банковских гарантий на сумму более 147 млрд руб., из которых 19,1 тыс. банковских гарантий (96\%) были приняты в виде электронного документа, подписанного усиленной квалифицированной электронной подписью. В 2019 году таможенными органами принято 18,5 тыс. банковских гарантий на сумму 115,7 млрд руб., из которых 17,1 тыс. банковских гарантий $(92,4 \%)$ были выданы в виде электронного документа, подписанного усиленной квалифицированной электронной подписью [1] (в 2018 году таможенными

органами принято 20,2 тыс. банковских гарантий на сумму 115 млрд руб., из которых 17,1 тыс. - электронные банковские гарантии).

Для обеспечения возможности передачи Евразийским банком развития информации о банковских гарантиях таможенным органам 16 июля 2020 года между Федеральной таможенной службой и Евразийским банком развития заключено Соглашение об информационном взаимодействии, техническая реализация которого будет осуществляться. в 2021 году.

Принято обеспечение на сумму более 37 млрд рублей (в 2019 году - более 40 млрд рублей). Уменьшение суммы принятого денежного обеспечения связано с увеличением использования участниками ВЭД таких способов обеспечения исполнения обязательства по уплате таможенных платежей, как банковская гарантия и поручительство.

В 2020 году залог имущества как способ обеспечения обязанности по уплате таможенных пошлин, налогов не применялся. С февраля 2020 года внедрена технология автоматического оформления таможенных расписок без участия сотрудников таможни, что позволило участникам внешнеэкономической деятельности самостоятельно распоряжаться своими денежными средствами для использования их в качестве обеспечения в рамках процедуры декларирования товаров [3].

В соответствии со статьей 65 Таможенного кодекса ЕАЭС размер обеспечения уплаты таможенных пошлин, налогов, на основании которого определяется размер обеспечения исполнения обязанности по уплате таможенных пошлин, налогов, применяются ставки таможенных пошлин, налогов, действующие на день регистрации заявления о выпуске товаров до подачи декларации на товары [2].

$$
* * *
$$

1. Официальный сайт ФТС России - www.customs.ru

2. Таможенный кодекс Евразийского экономического союза (приложение $\mathrm{N} 1$ к Договору о Таможенном кодексе Евразийского экономического союза) - Москва: Эксмо, 2020.

3. Сафонова Е.А. Совершенствование администрирования таможенных платежей // «Российская газета» - 2020. - №10. 